\title{
Metontology and the Body-Problem in Being and Time
}

\author{
Kevin Aho \\ Florida Gulf Coast University
}

It has been over fifty years since French philosophers began criticizing the "starting point" (Ausgang) of Being and Timespecifically Heidegger's account of average everyday practices, practices that initially give us "access" (Zugang) to the question of the meaning of being. In his essay, "The Philosophy of the Ambiguous," Alphonse de Waehlens argued Heidegger's phenomenological descriptions completely overlook the fundamental role that perception in particular and the body in general plays in our everyday practices. He says, "[In] Being and Time one does not find thirty lines concerning the problem of perception; one does not find ten concerning that of the body." Jean-Paul Sartre amplified this line of criticism when he emphasized the importance of the body as the first point of contact that a human being has with its world, a contact that is prior to detached theorizing about worldly objects. And Maurice Merleau-Ponty was indirectly critical of Heidegger insofar as he acknowledged the primacy of bodily perception, particularly in terms of our spatial directionality and orientation, an orientation that makes it possible for us handle worldly equipment in the first place. ${ }^{2}$

These early criticisms have since been developed and refined by English-speaking commentators such as Hubert Dreyfus, ${ }^{3}$ David Cerbone, ${ }^{4}$ and David Krell. ${ }^{5}$ Krell formulates the problem this way:

Did Heidegger simply fail to see the arm of the everyday body rising in order to hammer shingles onto the roof, did he overlook the quotidian gaze directed toward the ticking watch that overtakes both sun and moon, did he miss the body poised daily in its brazen car, a car equipped with a turn signal fabricated by and for the hand and eye of man, did he neglect the human being capable day-in, day-out of moving its body and setting itself in motion? If so, what conclusion must we draw ${ }^{6}$ 
These criticisms suggest what is missing in Heidegger's early project is a recognition of how the "lived-body" (Leib) participates in shaping our own understanding of being. ${ }^{7}$ Indeed, it is argued that the body should be regarded as an "existentiale" (Existenzial), an essential structure or condition for any instance of Dasein. Acknowledging the importance of these criticisms, I address the question of why Heidegger may have bypassed an analysis of the lived-body in the first place and where such an analysis might fit within the overall context of Heidegger's early project. ${ }^{8}$

In this paper, I suggest an analysis of Dasein's bodily nature can be undertaken as "metontology" (Metontologie) or "metaphysical ontics" (metaphysische Ontik), a term briefly introduced in Heidegger's 1928 Leibniz lectures, referring to a mode of ontic investigation already rooted in the outcome of the existential analytic of Dasein. I argue it is only after Dasein has been articulated as a disclosive temporal horizon-a horizon on the basis of which beings such as bodies can be understood-that philosophy can "return to" and "repeat" an interpretation of our bodily nature. 9 This return can commence only after traditional assumptions concerning the being of beings have been dismantled, specifically the assumption that the body is to be understood exclusively as $a$ being, a quantifiable, material thing.

\section{Dasein's Relation to the Body}

Early on in Being and Time, Heidegger provides a clue regarding where we should situate investigations of the body. He says, "One cannot think of [Dasein] as the being-present-at-hand of some corporeal Thing (such as a human body) 'in' an entity that is present-at-hand."10 For Heidegger, addressing the various objective characteristics of the body-size, weight, anatomy, biology - is not crucial to his project. Heidegger is, of course, not denying the fact that humans are bodily beings insofar as we are living organisms. Indeed, in his 1929-30 lectures, The Fundamental Concepts of Metaphysics, lectures devoted largely to the domain of biology, Heidegger claims the "living being is always an organism. Its organismic character is what determines the unity of this particular being." But human being (Dasein) should not be 
studied as if it were a living entity that is physically present. "When we designate this entity with the term 'Dasein'," says Heidegger, "we are expressing not its 'what' (as if it were a table, house, or tree) but its being." 12 Giving an account of Dasein's bodily 'whatness'- understood here as the material composition of a human being-does not help us come to grips with the unique way of being human. Thus, "we cannot define Dasein's essence by citing a 'what' . . . its essence lies rather in the fact that in each case it has its being to be."13 Heidegger will amplify this point twenty years later in his "Letter on Humanism."

The fact that physiology and physiological chemistry can scientifically explain man as an organism is no proof that in this 'organic' thing, that is, in the body scientifically explained; the essence of man exists. ${ }^{14}$

To focus on the "present-at-hand" attributes of Dasein is to perpetuate a brand of ontology that begins with Plato and Aristotle. Such ontology interprets the being (ousia) of beings in terms of "substance," where substance-the essence that 'stands under' or 'underlies'-is understood in terms of enduring "presence" (Anwesenheit). According to Heidegger, Western philosophy has lapsed into "fallenness" (Verfallenheit) because it continues to interpret the being of humans in terms of "presence" that remains the same through any change in attributes. Contemporary philosophers, in this regard, have largely jettisoned the immaterial mind or soul as the enduring being of humans and have replaced it with material substance that is quantifiable and causally determined.

Heidegger suggests traditional, substance-oriented ontology presupposes what is most essential to humans. Specifically, it overlooks the ongoing activity of everyday "existence" that initially makes it possible to theoretically represent things in terms of substance. "The existential nature of man," says Heidegger, "is the reason why man can represent beings as such, and why he can be conscious of them. All consciousness presupposes...existence as the essential of man."15 Prior to detached theorizing about the essential properties of things, I exist. I am practically engaged with a 
meaningful world - understood as a relational background of equipment, institutions, practices and others, and this background is already there. The essence or being of Dasein, therefore, is not to be found in an enduring substance. Rather, "the essence of Dasein lies in its existence."16

What is distinctive about human existence, according to Heidegger, is that we already embody a "vague and average" understanding of what it is to be. In short, in our everyday existence or "being-in-the-world," we grow into a tacit understanding of things; things are, for the most part, familiar and make sense to us. This understanding of things is not accomplished by detached staring or theorizing. We understand things insofar as we pre-reflectively handle, manipulate, and use them. A hammer, for instance, comes into being for me as a hammer insofar as I use it "in-orderto-hammer."

The less we just stare at the hammer-thing, and the more we seize hold of it and use it, the more primordial does our relationship to it become, and the more unveiledly is it encountered as that which it is-as equipment. ${ }^{17}$

Against the background of a pre-given world, things show up for us in meaningful ways to the extent that we practically use them in the course of our daily activities.

In order to get clear about how Dasein embodies a tacit understanding of being, Heidegger's project of fundamental ontology begins with an "analytic of Dasein" or "existential analytic." The method for his project is phenomenology which carefully describes how things meaningfully show up or come into being for us in the course of our everyday practices. The problem, however, is that Heidegger's descriptions of concrete existence in Being and Time fail to acknowledge the role of the body. Heidegger simply admits Dasein's “"bodily nature' hides a whole problematic of its own though we shall not treat it here."18 Critics rightly question why Heidegger is reluctant to offer an investigation of the practical skills and capacities of the body which initially give us access to intra-worldly beings and always accompany us in our everyday understanding. David Cerbone makes the point explicit: 
Given the prominence, and indeed the priority, of practical engagement with the world within Heidegger's conception of what it is to be human, an understanding of ourselves as embodied agents would seem to be a central concern, and not something whose treatment could be casually deferred. ${ }^{19}$

This criticism of Being and Time can be clarified by turning to Edmund Husserl's distinction between two senses of the body. For Husserl, the "lived-body" (Leib) is not a Cartesian/Newtonian body (Körper), not a corporeal mass with measurable attributes. ${ }^{20} \mathrm{Ac}$ cording to the Cartesian interpretation, bodies are defined in terms of (a) measurable weight, mass, shape, and motion, (b) occupying a specific spatial-temporal location, and (c) having determinate boundaries. Thus, rocks, trees, organisms, cultural artifacts, and human beings are all instances of Körper, but this definition does not help us understand how humans live as embodied agents in the world. The objectifying, quantifiable approach to understanding material bodies is itself derived from the perceptual, living body that initially orients me in the world. Heidegger will later acknowledge this distinction-particularly in his 1936-37 Nietzsche lectures and in his Zollikon Seminars from 1959-1971-by recognizing the limits of the interpretation of the body offered by the natural sciences. In his Nietzsche lectures, for example, Heidegger says:

Our being embodied is essentially other than merely being encumbered with an organism. Most of what we know from the natural sciences about the body and the way it embodies are specifications based on the established misinterpretation of the body as a mere natural body. ${ }^{21}$

With the distinction between the lived-body and material body in place, we can begin to see why it would be misleading to say Dasein is a bounded material being that occupies a particular spatial location. The lived-body stretches beyond corporeal limits, binding me to the nexus of tools and others that I am involved with in my daily activities. Indeed, as Merleau-Ponty will later suggest, the lived-body constitutes the perceptual horizon within which I handle intra-worldly things, and I am always already oriented within this horizon. In this regard, I embody a habitual, pre-reflective "know- 
how" (können) of where things are in terms of their relations to other things. If I visit New York City, for example, I already embody a kinesthetic understanding of how to walk down a crowded sidewalk. ${ }^{22}$ The mind does not tell my body to move two feet to the left to avoid an obstacle or a pedestrian. Indeed, in the flow of my everyday practices, the problem of mind/body interaction dissolves altogether. Prior to mental deliberations, I am already woven to the world in terms of embodied directions of 'right' and 'left', 'up' and 'down'. My daily life is pre-shaped by this connection with the surrounding environment, and the connection cannot be reduced to observable material that can be broken down to elemental causal interactions. ${ }^{23}$ Thus, "Everything we call our bodiliness," says Heidegger in his Zollikon Seminars, "down to the last muscle fiber and down to the most hidden molecule of hormones, [already] belongs essentially to existing." ${ }^{24}$

Consequently, it would be misleading to say Dasein is a being that has a material body. This runs the risk of interpreting Dasein in terms of the same substance categories of mind/body that Heidegger's project was attempting to overcome, misrepresenting Dasein as the immaterial understanding of being that 'inhabits' the material body. ${ }^{25}$ Furthermore, it overlooks the phenomenon of the living body itself, a phenomenon captured in the various ways I am concretely involved in the world, rather than something I 'have' or possess. "We do not 'have' a body," says Heidegger, "rather we "are' bodily." ${ }^{26}$ The lived-body is not a physical organism but what Heidegger will later call, the "bodying forth" (Leiben) of the body, which refers to our moving, perceptual engagement with the world. ${ }^{27}$ Critics suggest it is this rich interpretation of embodiment that helps to fully capture the sense of "being-in-the-world," and it is this interpretation that is noticeably absent in Being and Time.

Does this absence hinder Heidegger's project of fundamental ontology? Again, Being and Time is not overly concerned with regional ontology. Thus, it does not focus on the being of various beings (Seiendes) such as numbers, plants, animals, or humans. Fundamental ontology is concerned with the question of the meaning of being in general, with how any and all beings-including numbers, plants, animals, and humans-'can be' or emerge-into- 
presence as such in the first place. In this regard, Heidegger is concerned with "existentialia," the essential conditions or structures that constitute the "there" $(D a)$, the disclosive horizon or "clearing (Lichtung) that allows beings to be. To this end, Dasein does not, at the deepest level, refer to an individual or self, rather human existence is to be understood as the shared activity of opening up a horizon of meaning on the basis of which beings can show up as the kinds of beings that they are. Dasein, in this sense, refers to "the 'there' (das ' $D a$ '), that is, the lighting of being."28

\section{The Body and Temporality}

The question, for our purposes is this: Should the lived-body be regarded as an "existentiale," as an essential structure of this horizon? Heidegger lists many essential structures characteristic of Dasein, structures such as "being-in-the-world, in-being, beingwith, the Anyone, discoveredness, understanding, falling, and care."29 However, he identifies three master structures in Being and Time, "Situatedness" (Befindlichkeit), "Discourse" (Rede), and "Understanding" (Verstehen) which-taken together-underlie all other structures and constitute the essential conditions for disclosure, determining in advance beings as beings. ${ }^{30}$ Heidegger, however, makes it clear that uncovering these structures is "provisional." Fundamental ontology must finally arrive at "temporality" (Zeitlichkeit) as the ultimate source of meaning, the original "horizon for all understanding of being and for any way of interpreting it." ${ }^{31}$ Thus, for Heidegger, "the outcome of the existential analytic, the exposition of the ontological constitution of Dasein in its ground, is this: the constitution of the Dasein's being is grounded in temporality." 32

On the traditional view, according to Heidegger, time has been understood in Aristotelian terms as a successive sequence of 'nowpoints' that endlessly follow one after another, where one 'now' is "earlier and the other later." ${ }^{\text {"33 }}$ This view yields "clock-time" which measures and organizes these 'now-points' in terms hours, days, months, and years. And this measurement is always accomplished in reference to the "present." In his 1924 Marburg lecture, The Concept of Time, Heidegger says: 
The clock shows us the now, but no clock ever shows the future or has ever shown the past .... The time made accessible by a clock is regarded as present ... past is interpreted as no-longer present, future as indeterminate not-yet-present. ${ }^{34}$

Against this view, Heidegger suggests sequential clock-time is itself derived from and made possible by "primordial temporality." For Heidegger, this means the question: "What is time?" is itself illconceived. The more appropriate question is: "Who is time?"35

For Heidegger, primordial temporality must be understood in terms of human existence, and existence stretches in three directions, from out of the "present" (Gegenwart), into the "future" (Zukunft) and back to the "past" (Gewesenheit). Primordial time is, therefore, understood as a holistic, non-successive manifold of three dimensions or "ecstasies." In the "present" I am practically immersed in a context of tools and others as I go about my life. However, my practical involvement with things is always mediated by the "past" and the "future," by the temporal structures of "situatedness" (Befindlichkeit) and "projection" (Entwurf). Situatedness refers to the way in which I am already "thrown" into a shared world, with a shared history that attunes or affects me in terms of particular dispositions or "moods" (Stimmung). Projection refers to the way I am always "ahead of" myself in my everyday activities insofar as I am directed forward by future goals and projects, by the "for-the-sake-of-which" (das Worumwillen). It is only on the basis of this disclosive horizon - one that simultaneously reaches forward into social possibilities and projects that are "not yet" and backward into a shared situation that allows things to count and matter in particular ways - that beings can emerge-intopresence as such.

Where would the lived-body fit within this twofold horizon? We can look at projection first. Because Entwurf captures the sense of Dasein as a being "on the way" or "ahead of itself" it is fundamentally futural. ${ }^{36}$ As such, Dasein is structurally "beingtowards-the-end" or "being-towards-death" which has nothing to do with our bodily demise. In the bodily sense, "Dasein never perishes." 37 Death, therefore, does not refer to the end of a successive sequence of 'now-points'. 
The end of my Dasein, my death, is not some point at which a sequence of events suddenly breaks off, but a possibility which Dasein knows of in this or that way: the most extreme possibility of itself, which it can seize and appropriate as standing before it. $^{38}$

For Heidegger, death is a structure of disclosedness itself, indicating how human existence always moves towards the possibility of its own completion or fulfillment even though such fulfillment is impossible. As a finite movement, I am not something fundamentally fixed or stable. I am more like a "not yet" because I can always move into different social possibilities right up until the moment of death. As Heidegger says, "this 'not yet' belongs to Dasein as long as it is." 39 Thus, Entwurf reveals how Dasein is a "being-possible," a "potentiality" or "not yet" that can never attain "wholeness." bilities', it is hard to see how the 'actual' event of concrete "bodying forth" (Leiben) could be found in projection. Indeed, in his Zollikon Seminars, Heidegger confirms, "bodying forth does not occur here." $" 41$

The structure of Befindlichkeit seems to be a more likely candidate. Again, situatedness-taken together with projectionconstitutes Dasein's temporal openness. It is by means of projection that I already understand the world and press into future possibilities, and it is by means of situatedness that I find myself in a particular public situation where things affect me or matter to me in terms of shared dispositions. In this respect, the lived-body appears to be a necessary condition of situatedness insofar as I am thrown into a particular concrete situation, and this situation is disclosed to me in terms of specific embodied attunements.

This may provide us with a clearer picture of Heidegger's claim in the Zollikon Seminars, specifically that "bodying-forth" should be regarded as "a necessary but not a sufficient condition" for any relation with the world. ${ }^{42}$ The lived-body can be interpreted as a 'necessary' condition for any instance of Dasein because it is an essential aspect of the temporal structure of situatedness. But it is not a 'sufficient' condition because it is nowhere to be found in the temporal structure of projection. Heidegger says: 
Bodying forth (Leiben) as such belongs to being-in-the-world. But being-in-the-world is not exhausted in bodying forth. For instance, the understanding of being also belongs to being-inthe-world. ${ }^{43}$

If this is true, the lived-body must therefore be understood as an essential structure of intelligibility because it constitutes half of the twofold horizon of temporality.

Does this mean, as commentators such as Brian Bowles suggest, that "bodying forth" should be interpreted as isomorphic with "situatedness?"44 It is not so simple. First, this suggestion puts too much emphasis on the role of the individual subject in terms of the constitution of our specific attunements or moods. Furthermore, it fails to distinguish between my own embodied agency and the disclosive horizon that is already there, a horizon that gives meaning to my embodied practices. We will look at each of these problems in turn.

Heidegger's use of Stimmung is not to be understood subjectively where the world meaningfully affects me in terms of my own psychological 'states-of-mind', being depressed, afraid, bored, or excited. Rather, Stimmung is the condition for the possibility of any individual disposition or mood. The mood is not in $m e$, in the lived-body; I am already in a mood by virtue of my public involvements, by being thrown into a shared social context that determines in advance the way things affect me. In short, mood is "like an atmosphere," already "there" prior to the emergence of the lived-body, and it is by means of this atmosphere that my embodied engagements are attuned or disposed in one way or another towards things. In his 1929-30 lectures, Heidegger says

Attunements are not side-effects, but are something which in advance determines our being with one another. It seems as though attunement is in each case already there, so to speak, like an atmosphere in which we first immerse ourselves in each case and which then attunes us through and through. ${ }^{45}$

Hence, moods are both a priori and public, making it possible for me, as an embodied agent, to be in a mood. 
The dominance of the public way in which things have been interpreted has already been decisive even for the possibilities of having a [mood] - that is, for the basic way in which Dasein lets the world "matter" to it. ${ }^{46}$

For Heidegger, moods reveal the way communal events, roles, occupations, and equipment already matter to us. For instance, the practices of a teacher, husband, or father matter to me because they are part of the world I am familiar with, whereas the practices of a shaman, witchdoctor, or tribal chief do not show up in terms of this familiar nexus of relations, and therefore they do not shape the future course of my life. Thus, moods disclose a basic temporal structure of Dasein, the structure of "alreadiness," that is prior to my own embodied agency. Heidegger puts it in the following way:

Why can I let a pure thing of the world show up at all in bodily presence? Only because the world is already there in thus letting it show up ... ${ }^{47}$

It is only if our embodied acts and practices are structured by the past, by situatedness, that we can be attuned to the world in the first place. We can say the lived-body gives us access to intraworldly things and is, therefore, required for any human being to be in a mood, but the lived-body does not constitute the meaningfulness of moods or make them possible. Moods, like the world itself, are already there for us to grow into. ${ }^{48}$

To this end, Being and Time involves two interpretations of Dasein. The project begins with phenomenological descriptions of my own embodied activities, activities that reveal a particular understanding of being, what Heidegger calls "existentiell" understanding.

The question of existence never gets straightened out except through existence itself. The understanding of oneself which leads along this way we call existentiell. ${ }^{49}$

My worldly practices embody a particular understanding of being because I am invariably engaged in specific social roles that are 
already meaningful. It is, therefore, by means of my own activities that I draw things into a meaningful public space. Thus, Dasein's individual activity opens up and sustains a clearing. ${ }^{50}$

However, describing my own embodied understanding of being is only the first step. Heidegger's core concern is the original horizon of meaning itself. In this more primordial sense, Dasein is to be understood as the Da-sein, as the "being of the-there," the clearing that makes meaningful bodily acts and practices possible. Here, the emphasis is not on the particular embodied engagements of the individual but on temporality as the " $D a$," the disclosive space or "openness" that lets beings show up in their being. It is for this reason that Heidegger, in his 1928 Leibniz lectures, refers to Dasein's openness as "neutral" because it is prior to the livedbody, "prior to every factual concretion." 51 It is what makes "bodiliness," "sexuality," and "concrete factual humanity" possible. As embodied agents we are already "stretching along" forward and backward in a meaningful, temporally structured horizon. ${ }^{52}$

Moreover, Heidegger suggests this horizon of temporality is itself "made possible by some primordial way in which ecstatical temporality temporalizes." ${ }^{.53}$ In his 1927 lecture course, The Basic Problems of Phenomenology, Heidegger refers to this most original form of temporality with the Latinate "Temporalität." 54 Temporalität is seen as the origin of any possibility whatsoever, and as such, it is "earlier" than any bodily comportment or individual understanding of being.

Time is earlier than any possible earlier.... Time as the source of all enablings (possibilities) is the earliest, all possibilities as such in their possibility-making function have the character of the earlier. That is to say, they are a priori. ${ }^{5 s}$

We can say, therefore, the lived-body ek-sists by "standing outside" itself insofar as it is already embedded in and engaged with a meaningful public background. As such, the embodied agent "transcends" the binary of subject and object, surpassing the boundaries of her own skin because she is already directed towards and handling intra-worldly beings. But this transcendence is itself made possible by the horizonal unity of temporalizing. 
As the ecstatic-horizonal unity of temporalizing, temporality is the condition of the possibility of transcendence and thus also the condition of possibility of the intentionality that is founded in transcendence .... Temporality makes possible Dasein's comportment as comportment toward beings, whether toward itself, toward others, or toward the handy or the extent. ${ }^{56}$

So Temporalität is understood as prior to and the condition for the possibility of any instance of meaningful embodied living.

\section{The Importance of Metontology}

Fundamental ontology, therefore, ultimately reveals Temporalität as the origin of any intelligibility, an origin stripped of all ontic determinations including the factical aspects of my own bodily nature. However, critics rightly point out that this results in a project that becomes increasingly "formal," "neutral," and "abstract," withdrawing and finally severing itself from, what Heidegger refers to as, the "ontical priority of Dasein," the concrete starting point for any fundamental ontology. ${ }^{57}$ Heidegger confirms, "The results of the [existential] analysis show the peculiar formality and emptiness of any ontological determination." ${ }^{88}$ Yet, this does not mean Heidegger is dismissing investigations into the problem of embodiment altogether. Indeed there are clues in his lectures following Being and Time indicating that the existential analytic opens up the possibility of "turning" (Kehre) back to the ontic aspects of Dasein, a turn now rooted in the "primal phenomenon of human existence itself." ${ }^{59}$ This return is not inconsistent with the position in Being and Time. For Heidegger, it is on the basis of the worldly, existentiell practices of ontic Dasein that any ontology "arises" and must eventually "return."60

The nature of this "turn around" or "overturning" (Umschlag) is only briefly introduced in an appendix to his 1928 Leibniz lectures where Heidegger distinguishes the "analytic of Dasein" from the "metaphysics of Dasein." ${ }^{\text {"I }}$ It is on the basis of the metaphysics of Dasein that philosophy can return to specific anthropological and ethical aspects of existence that were passed over in the existential analytic. ${ }^{62}$ In his 1929 lectures, Kant and the Problem of 
Metaphysics, Heidegger explains that the metaphysics of Dasein is nothing like a "fixed" conceptual system "about" a particular entity, as for example "zoology is about animals." Rather, it is always transforming and being taken up anew, always working out the question of "what man is."63 Heidegger refers to this new investigation, which re-examines the existentiell practices of Dasein, as "metontology" (Metontologie)

I designate this set of questions metontology. And here also, in the domain of metontological-existentiell questioning, is the domain of the metaphysics of existence. ${ }^{64}$

Metontology or "metaphysical ontics" (metaphysische Ontik) is not a reference to the ontic investigations of the positive sciences.

[M]etontology is not a summary ontic in the sense of a general science that empirically assembles the results of the individual sciences into a so-called "world picture." 65

Metontology is associated with the ontic sciences only insofar as it has "beings as its subject matter." In short, Dasein is now thematized as $a$ being, but not in terms of its objective, present-at-hand attributes. Rather, it is thematized in terms of existence. Metontological-existentiell questioning, therefore, is already shaped by the results of the analytic of Dasein. It is for this reason that Heidegger suggests an essential union between fundamental ontology and metontology. "Metontology is only possible," says Heidegger, "on the basis and in the perspective of the radical ontological problematic and is possible conjointly with it."66

On the metontological view of the body, the assumptions of the positive sciences have been dismantled, and the body is no longer conceived exclusively as a bounded material entity that is separate and distinct from worldly objects. The body-now understood in terms of existence-is already at home, oriented in a concrete situation, pre-reflectively handling and manipulating a holistic totality of beings. As an embodied agent I am already familiar with a unified, pre-given background and this embodied familiarity allows things - such as tools, signs, gestures, and events-to show up as 
the very things that the are. This means body and world are not cut off from each other like subject and object. Rather, they always "belong together" in terms of Dasein."

At the end of Being and Time, Heidegger suggests that his own ontical starting point-which provides access to the question of the meaning of being -is only one possible path. "Whether this is the only way or even the right one at all," says Heidegger, "can be decided only after one has gone along it." ${ }^{18}$ Heidegger, therefore, recognizes his path is "limited," and it will invariably neglect certain factical aspects of existence. ${ }^{69}$ These aspects can be taken up again by metontology, by the metaphysics of Dasein. And philosophy will inevitably return to the concerns of metontology because the existential analytic is itself made possible by a metaphysics of finite historical existence. ${ }^{70}$ Indeed, as Heidegger says in 1929, fundamental ontology is only "the first level" of the metaphysics of Dasein.

The metaphysics of Dasein, guided by the question of groundlaying, should unveil the ontological constitution of [Dasein] in such a way that it proves to be that which makes possible [the existentiell] ... Fundamental ontology is only the first level of the metaphysics of Dasein. What belongs to this [Metaphysics of Dasein] as a whole, and how from time to time it is rooted historically in factical Dasein cannot be discussed here."11

It can be argued that this theme endures in Heidegger. As late as his 1962 lecture, On Time and Being, Heidegger expressed the importance of repeating an analysis of the ontic aspects of Dasein after the "meaning of being had been clarified," features that the positive sciences were never able to grasp and thus had to be taken up in a "completely different way." Heidegger, On Time and Being, trans. Joan Stambaugh (New York: Harper and Row, 1972) 32 .

\section{Notes}

' Alphonse de Waelhens, "The Philosophy of the Ambiguous," in Maurice Merleau-Ponty's The Structure of Behavior, trans. Alden L. Fisher (Boston: Beacon Press) xix. 
${ }^{2}$ See Richard Askay's article "Heidegger, the body, and the French philosophers," Continental Philosophy Review 32 (1999): 29-35.

${ }^{3}$ Hubert Dreyfus, Being-in-the-World: A Commentary on Heidegger's Being and Time Division I (Cambridge: MIT Press, 1991).

${ }^{4}$ David Cerbone, "Heidegger and Dasein's Bodily Nature: What is the Hidden Problematic?" International Journal of Philosophical Studies 33 (2000): 209-230. Indiana University Press, 1992).

${ }^{6} \mathrm{Krell}$, Daimon Life, 152.

${ }^{7}$ It is important to note that Heidegger was certainly aware of the problem of the body and addressed it frequently over the years. In Being and Time, for example, he acknowledges the importance of the spatial directionality of the body. And he continues to address the topic of embodiment in his 1929-30 lectures Fundamental Concepts of Metaphysics, in his Nietzsche lectures of 1936-37, in the Letter on Humanism in 1947, and, most importantly, in the Zollikon Seminars from 1959-1971. But he also recognizes that the topic presents special difficulties. In his Heraclitus seminars of 1966-67, Heidegger refers to the body problem as "the most difficult problem." See Heidegger, Heraclitus Seminar, trans. Charles H. Seibert (Birmingham: University of Alabama Press, 1970) 147. And, in 1972, Heidegger admits that he was unable to respond to earlier French criticism of the neglect of the body in Being and Time because "the bodily [das Leibliche] is the most difficult [problem to understand] and I was unable to say more at the time." See Heidegger, Zollikon Seminars, trans. Franz Mayr and Richard Askey (Evanston: Northwestern University Press, 2001) 231.

${ }^{8}$ In this regard, this paper is largely an attempt to develop and improve on ideas initially introduced in a comparative study of mine, "The Missing Dialogue between Heidegger and Merleau-Ponty: On the Importance of the Zollikon Seminars," in Body and Society 11 (2005): 1-23. In this earlier piece, I suggested that any analysis of Dasein's body-nature is merely ontic and, consequently, not crucial to Heidegger's project of fundamental ontology. However, I failed to distinguish between the ontic or positive sciences and what Heidegger will call "metaphysical ontics" or "metontology." For Heidegger, metontology-a discipline which returns to the factical aspects of existence-can begin only after the assumptions of the positive sciences have been suspended and the question of the meaning of being has been clarified.

${ }^{9}$ Martin Heidegger, Being and Time, trans. John Macquarrie and Edward Robinson (Oxford: Blackwell Press, 1962) 38, 439. All citations refer to the original German pagination.

${ }^{10}$ Heidegger, Being and Time, 54. 
"Heidegger, Fundamental Concepts of Metaphysics: World, Finitude, Solicitude, trans. William McNeill and Nicholas Walker (Bloomington: Indiana University Press, 1995) 212.

${ }^{12}$ Heidegger, Being and Time, 42.

${ }^{13}$ Heidegger, Being and Time, 12-13.

${ }^{14}$ Heidegger, "Letter on Humanism," in David Krell (ed.) Basic Writings, (San Francisco: HarperCollins, 1977) 205.

${ }^{15}$ Heidegger, "On the Way Back Into the Ground of Metaphysics" in Walter Kaufmann (ed.) Existentialism from Dostoevsky to Sartre, (New York: Meridian Books, 1956) 272.

${ }^{16}$ Heidegger, Being and Time, 42.

${ }^{17}$ Heidegger, Being and Time, 69, my emphasis.

${ }^{18}$ Heidegger, Being and Time, 108.

${ }^{19}$ Cerbone, "Heidegger and Dasein's Bodily Nature," 210.

${ }^{20}$ This distinction is introduced in Part One and explored in depth in Part Three, sections 28 and 62 of Husserl's The Crisis of European Sciences and Transcendental Philosophy, trans. David Carr (Evanston: Northwestern University Press, 1970).

${ }^{21}$ Heidegger, Nietzsche, Volume One: The Will to Power as Art, trans. David Krell (New York: Harper and Row, 1979) 99-100.

${ }^{22}$ See Kevin Aho, "The Missing Dialogue between Heidegger and Merleau-Ponty," 8-9.

${ }^{23}$ See Charles Taylor, "Engaged Agency and Background in Heidegger," in Charles Guignon (ed.) The Cambridge Companion to Heidegger (Cambridge University Press, 1993)

${ }^{24}$ Heidegger, Zollikon Seminars, 232.

${ }^{25}$ I am borrowing from David Cerbone who writes, "Treating the body as a mere thing which Dasein in some way infuses or inhabits is apt to bring with it the suspicion that dualism has not so much been overcome, as simply redescribed. Given the anti-Cartesian aspirations that inform Being and Time and Heidegger's other early writings, this suspicion should be particularly unwelcome." See Cerbone, "Heidegger and Dasein's Bodily Nature," 217.

${ }^{26}$ Heidegger, Nietzsche, 98, my emphasis.

${ }^{27}$ Heidegger, Zollikon Seminars, 86.

${ }^{28}$ Heidegger, "Letter on Humanism," 205.

${ }^{29}$ Heidegger, History of the Concept of Time, trans. Theodore Kisiel (Bloomington: Indiana University Press, 1985) 305.

${ }^{30}$ Heidegger, Being and Time, 5. At the end of Chapter Five in Being and Time, Heidegger explains how his investigations have unearthed these three structures and also derive a fourth structure, "falling" 
(Verfallen). Having accomplished this, Heidegger can now move on to the Second Division in order to explain this totality of structures or "carestructure" in terms of temporality.

The being of that disclosedness is constituted by situtatedness, understanding, and discourse. Its everyday kind of being is characterized by idle talk, curiosity, and ambiguity. These show us the movement of falling, with temptation, tranquillizing, alienation, and entanglement as its essential characteristics.

But with this analysis, the whole existential constitution of Dasein has been laid bare in its principle features, and we have obtained the phenomenal ground for a "comprehensive" interpretation of Dasein's being as care.

See Heidegger, Being and Time, 224.

${ }^{31}$ Heidegger, Being and Time, 17

${ }^{32}$ Heidegger, The Basic Problems of Phenomenology, trans. Alfred Hofstadter (Bloomington: Indiana University Press, 1982) 228.

${ }^{33}$ Heidegger, The Concept of Time, trans. William McNeill (Oxford: Blackwell Press) 4.

${ }^{34}$ Heidegger, The Concept of Time, 17.

${ }^{35}$ Heidegger, The Concept of Time, 22.

${ }^{36}$ Heidegger, Being and Time, 243.

${ }^{37}$ Heidegger, Being and Time, 247

${ }^{38}$ Heidegger, The Concept of Time, 11.

${ }^{39}$ Heidegger, Being and Time, 242.

${ }^{40}$ Heidegger, Being and Time, 145, 236

${ }^{41}$ Heidegger, Zollikon Seminars, 197.

${ }^{42}$ Heidegger, Zollikon Seminars, 231.

${ }^{43}$ Heidegger, Zollikon Seminars, 197.

${ }^{44}$ Brian Bowles, "Heidegger and the Absence of the Body: The Zollikoner-Seminare," International Studies in Philosophy 33 (2001) 19-20. ${ }^{45}$ Heidegger, The Fundamental Concepts of Metaphysics, 67.

${ }^{46}$ Heidegger, Being and Time, 169-70.

${ }^{47}$ Heidegger, History of the Concept of Time, 196, my emphasis.

${ }^{48}$ Consequently, I disagree with Brian Bowles when he says "our bodily nature is what accounts for our situatedness and our attunedness ... In the places of alreadiness and becoming we find thrownness (Geworfenheit) and projection (Befindlichkeit) and understanding (Verstehen), and now bodying (Leiben) and the understanding of being (Seinsverständnis). All of these pairs should be seen as more or less equivalent insofar as they map onto the essentially two-fold but unified 
structure of existence." See Bowles, "Heidegger and the Absence of the Body: The Zollikoner Seminare," 19-20.

${ }^{49}$ Heidegger, Being and Time, 12.

${ }^{50}$ See Dreyfus, Being-in-the-World, 163-4.

${ }^{51}$ Heidegger, The Metaphysical Foundations of Logic, trans. Michael Heim (Bloomington: Indiana University Press, 1984) 136.

52 Heidegger, The Metaphysical Foundations of Logic, 137-38.

${ }^{53}$ Heidegger, Being and Time, 437.

${ }^{54}$ Heidegger, Basic Problems of Phenomenology, 302.

${ }^{55}$ Heidegger, Basic Problems of Phenomenology, 325.

${ }^{56}$ Heidegger, Basic Problems of Phenomenology, 318.

57 See Robert Bernasconi, "Fundamental Ontology, Metontology, and the Ethics of Ethics," Irish Philosophical Journal 4 (1987) 76-93.

${ }^{58}$ Heidegger, Being and Time, 248.

${ }^{59}$ Heidegger, The Metaphysical Foundations of Logic, 156.

${ }^{60}$ Heidegger, Being and Time, 38, 436.

${ }^{61}$ Heidegger, Metaphysical Foundations of Logic, 156. However, it is important to note, as Robert Bernasconi does, that one must be cautious in reading too much into the word "metontology" because it never made its way into Heidegger's published writings. See Bernasconi, "Fundamental Ontology, Metontology, and the Ethics of Ethics," 83.

${ }^{62}$ See Karin de Boer, Thinking in the Light of Time: Heidegger's Encounter with Hegel (Albany: State University of New York Press, 2000) 42-3.

${ }^{63}$ Heidegger, Kant and the Problem of Metaphysics, trans. Richard Taft (Bloomington: Indiana University Press, 1990) 162.

${ }^{64}$ Heidegger, The Metaphysical Foundations of Logic, 157.

${ }^{65}$ Heidegger, The Metaphysical Foundations of Logic, 157.

${ }^{66}$ Heidegger, The Metaphysical Foundations of Logic, 157. Heidegger goes so far as to say that, "in their unity, fundamental ontology and metontology constitute the concept of metaphysics." See Heidegger, The Metaphysical Foundations of Logic, 158.

${ }^{67}$ Heidegger, Basic Problems of Phenomenology, 297.

${ }^{68}$ Heidegger, Being and Time, 437.

${ }^{69}$ Heidegger, Being and Time, 17.

${ }^{70}$ This re-examination is "decisive," as William McNeill suggests, in opening up the possibility of renewed meditations on the political and ethical nature of Dasein insofar as these domains involve analyses of the concrete comportment of human beings. See McNeill, "Metaphysics, Fundamental Ontology, and Metontology 1925-35," Heidegger Studies/ Heidegger Studien 8 (1992) 63-79. Heidegger confirms this point by say- 
ing it is only in the existentiell domain of metontology where "the question of ethics can first be raised." See Heidegger, The Metaphysical Foundations of Logic, 137

${ }^{71}$ Heidegger, Kant and the Problem of Metaphysics, 163.

7 Heidegger, On Time and Being, trans. Joan Stambaugh (New York: Harper and Row, 1972) 32.

Kevin Aho (PhD University of South Florida) is Assistant Professor of Philosophy at Florida Gulf Coast University. His area of research is contemporary European philosophy, particular topics in phenomenology and existentialism. 